Naukovyy visnyk Pivdennoukrayinskoho derzhavnoho universytetu im. K.D. Ushynskoho, V.9-10, pp. 118-126, 2014.

[2] V.P. Bezpalko, Yu.G. Tatur Sistemno-metodicheskoye obespecheniye uchebno-vospitatelnogo processa podgotovki spetsialistov. M.: Vysshaya shkola, 1989.

[3] V.A. Slastenyn Pedahohyka professyonalnoho obrazovaniya. M: Yzdatelskiy centr "Akademiya", 2004.

[4] V.P. Bezpalko Obrazovaniye $i$ obucheniye s uchastiyem komputerov (Pedagogika tretyego tisyacheletiya). M.: Izdatelstvo Moskovskogo Psikhologo-sotsialnogo instituta; Voronezh: Izdatelstvo NPO «MODEK», 2002.

[5] S.I. Arkhangelskiy Uchebnyy process v vysshey shkole, yego zakonomerniye osnovy i metody. M.: Vyssh. Shkola, 1980.

Література

[1] Лобода Ю.Г. Деякі аспекти застосування комп'ютерно-інтегрованих технологій у процесі навчання / Науковий вісник Південноукраїнського державного університету ім. К.Д. Ушинського, Вип.9-10., 2007. - С.118-126.

[2] Беспалько В.П., Татур Ю.Г. Системно-методическое обеспечение учебно-воспитательного процесса подготовки специалистов. / М.: Высшая школа, 1989.

[3] Сластенин В.А. Педагогика профессионального образования. / М: Издательский центр "Академия", 2004.

[4] Беспалько В.П. Образование и обучение с участием компьютеров (Педагогика третьего тысячелетия). / М: Издательство Московского Психолого-социального института; Воронеж: Издательство НПО «МОДЭК», 2002.

[5] Архангельский С.И. Учебный процесс в высшей школе, его закономерные основы и методы. / М.: Высш. школа, 1980.

\title{
ОСНОВНІ НАПРЯМКИ ТА ПЕРСПЕКТИВИ НАУКОВОГО РОЗВИТКУ ИНЖЕНЕРНОЇ МЕХАНІКИ, АВТОМАТИЗАЦЇ̈ ТА КОМП'ЮТЕРНИХ НАУК В ОДЕСЬКІЙ НАЦІОНАЛЬНІЙ АКАДЕМІЇ ХАРЧОВИХ ТЕХНОЛОГІЙ
}

\author{
Г. Ангелов ${ }^{1}$, В. Волков ${ }^{2}$, О. Кананихіна ${ }^{3}$, А. Соловей $^{4}$, О. Тітлова $^{5}$, Ф. Трішин $^{6}$ \\ 1,2,3,4,5,6 Одеська національна академія харчових технологій \\ ORCID: ${ }^{2} 0000-0002-3990-8126$ \\ E-mail: ${ }^{1}$ sociologia.kafedra@mail.ru, ${ }^{2}$ viktor@te.net.ua, ${ }^{3} \mathrm{k} \_$elni@ukr.net, ${ }^{4}$ solovanat56@mail.ru, ${ }^{5}$ titlova@ukr.net, \\ ${ }^{6}$ kindteacher@mail.ru
}

Copyright (C) 2017 by author and the journal "Automation technological and business - processes".

This work is licensed under the Creative Commons Attribution International License (CC BY).

http://creativecommons.org/licenses/by/4.0/

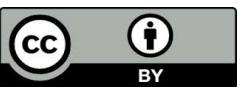

ONAFT

Open Access

Анотація: Розглянуто основні напрямки та перспективи наукового розвитку інженерної механіки, автоматизації та комп'ютерних наук в їх взаємозв'язку. Показано як світові тендениії знаходять своє відображення в історії Одеської національної академії харчових технологій.

Abstract: The main directions and perspectives of scientific development of engineering mechanics, automation and computer sciences are considered in their interconnection. It is shown how world trends are reflected in the history of the Odessa National Academy of Food Technologies.

Ключові слова: механіка, інженерна механіка, механізація, автоматизація, робототехніка, комп’ютерні науки.

Keywords: mechanics, engineering mechanics, mechanization, automation, robotics, computer science.

Вступ

Історія Одеської національної академії харчових технологій (ОНАХТ), її становлення та подальший розвиток нерозривно пов'язані з розвитком інженерної механіки як галузі науки та напрямку освіти. Навчальні плани створеної 
в 1902 році Одеської школи борошномелів, а в подальшому - Одеського млино-технічного училища (з 1909 року), технікуму технології зерна і борошна (з 1922 року), Одеського політехнікуму технології зерна і борошна (з 1928 року), включали в себе цілий комплекс дисциплін механічного напрямку. В 1928 році механічне відділення було реорганізовано в механічний факультет, який став самостійним структурним підрозділом. Подальші реорганізації структурних підрозділів ВНЗ в усі наступні роки зберігали в якості одного з пріоритетних напрямів підготовку инженерів-механіків. Такий підхід був насамперед пов'язаний з широким застосуванням механізмів в усіх галузях виробництва, в тому числі - в харчовій та в зернопереробній промисловості.

Механізація являє собою заміну ручної праці роботою машин. Розрізняють так звану часткову механізацію (коли машини або механізми виконують тільки окремі ручні операції) та комплексну механізацію (що охоплює весь комплекс робіт по створенню певного виробу або виконанню закінченого технологічного процесу).

Вчені-механіки ОНАХТ завжди займалися вивченням широкого кола питань теоретичної та прикладної механіки. При цьому прикладна механіка в широкому сенсі слова вбирає в себе не тільки опір матеріалів, теорію машин і механізмів та деталі машин, але й наукові проблеми технологічного обладнання та машинобудування.

Після закінчення Другої світової війни у ВНЗ працювала ціла низка видатних вчених, що спеціалізувалися на розв'язанні різноманітних проблем механіки. До тої славної плеяди належать професори В.Я. Білецький, О.М. Дзядзіо, М.Я. Дікіс, Л.Й. Котляр, Є.Б. Лунц, В.Ф. Мальцев, П.М. Платонов.

Петро Микитович Платонов обіймав посаду ректора академії в $з$ 1948-го по 1967-ий рік. Паралельно він тривалий час завідував кафедрою підйомно-транспортних машин (ПТМ), що входила до складу механічного факультету. В 1960 році П.М. Платонов захистив докторську дисертацію на тему «Дослідження руху зернових потоків». Основні ідеї цього дослідження знайшли свій подальший розвиток в наукових працях учнів Петра Микитовича - Б.І. Іванова, Л.I. Карнаушенко, М.К. Наремського, В.Г. Лебединського та багатьох інших.

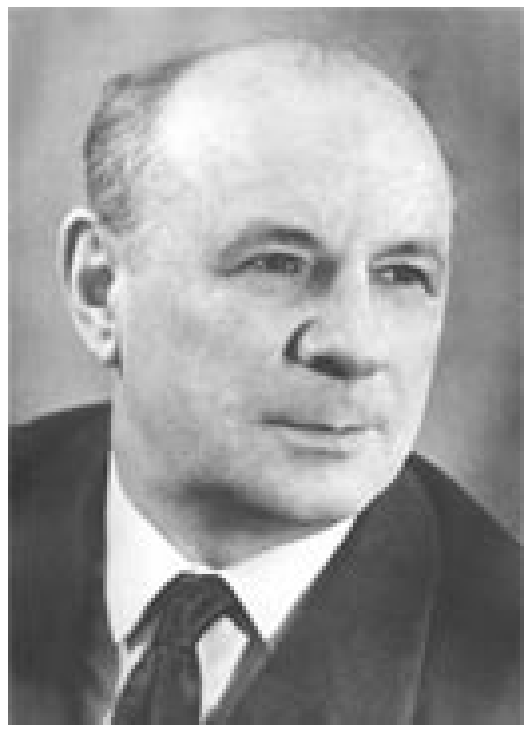

Рис. 1 - Професор Петро Микитович Платонов

За базовою освітою П.М. Платонов був інженером-механіком, в 1932 році він закінчив механічний факультет Одеського інституту технології зерна і борошна (таку назву носила тоді ОНАХТ). Але як людина широких наукових поглядів Петро Микитович одним 3 перших зрозумів, що якісно вищим ступенем механізації є автоматизація.

Справді, якщо (як зазначено вище) механізація $є$ заміною ручної праці роботою машини, то автоматизація $є$ заміною розумової праці людини роботою машини. Якщо при комплексній механізації цим комплексом машин керує робітник, то автоматизація передає керування машинами від робітника іншим машинам, а робітник лише налагоджує і контролює виробничий процес.

В такому сенсі автоматизація є продовженням механізації, іiї підняттям на більш високий ступінь. Без відповідної механізації автоматизація: 1) неможлива; 2) не має сенсу.

В 70-ті-80-ті роки минулого століття головним напрямом технічного прогресу, основою підвищення продуктивності праці та поліпшення якості продукції стала комплексна механізація та автоматизація виробництва. Цей напрям і зараз лишається одним з основних.

В 1960 році кафедру ПТМ зусиллями П.М. Платонова (на той час завідувача кафедри та ректора ВНЗ) було перетворено в кафедру механізації та автоматизації виробництв (МАВ). Професор Платонов став і першим завідувачем нової кафедри. Шістдесяті роки характеризуються швидким розвитком кафедри МАВ: створюються навчальні лабораторії промислової електроніки, обчислювальної техніки, технологічних вимірювань та приладів, здійснюється модернізація лабораторії автоматизації виробничих процесів. 
Розвиток кібернетики та автоматизації (яку можна розглядати як практичну кібернетику) відобразився в ОНАХТ безпосередньо перетворенням в 1969 році кафедри МАВ в кафедру автоматизації виробничих процесів (АВП), а також створенням за ініціативою ректора П.М. Платонова у 1963 році факультету автоматизації та приладобудування, першим деканом якого став доцент М. К. Наремський. І хоча в 1977 році факультет було об'єднано з механічним факультетом і створено новий факультет - механіко-технологічний і автоматики (МТА), вже в 1992 році за ініціативою ректора М.Д. Захарова та проректора $з$ наукової роботи, завідувача кафедри АВП професора Е.Й. Жуковського було створено факультет автоматизації технологічних процесів (АТП) шляхом виділення його зі складу факультету МТА.

Паралельно з розвитком автоматизації та у тісному зв'язку з нею у світі йшов бурхливий розвиток інженерної та прикладної механіки. Відповідно в ОНАХТ з'явилися нові наукові школи - школи професорів О. К. Гладушняка, Р.В. Амбарцумянца, А.О. Чижа, Ю.Ф. Копелєва, О.І. Гапонюка. Всі вони, та чи інакше, вирішуючи наукові проблеми механіки, торкалися і проблем автоматизації.

Отже науковий розвиток автоматизації та інженерної механіки завжди відбувався у тісному зв'язку - як у світі в цілому, так і конкретно в ОНАХТ. Але в останні роки намітилися певні тенденції (насамперед в розвитку автоматизації), що роблять цей зв'язок менш тісним, хоча й більш глибоким.

Механіка і автоматизація розвиваються паралельно, розширюючи свої наукові області та функції. Такий екстенсивний розвиток обох наукових галузей звичайно знижує рівень взаємозв'язків між ними. 3 іншого боку зростає взаємодія як інженерної механіки, так і автоматизації з іншими (досить різними) галузями знань. Проблема полягає в тім, щоб зберігаючи історичні зв'язки між механікою та автоматизацією, надати новий імпульс їх розвитку. В ОНАХТ це має найти відображення у структурних перетвореннях.

Постановка проблеми та ії зв'язок з важливими науковими та практичними проблемами

Механіка і автоматизація розвиваються паралельно, розширюючи свої наукові області та функції. Такий екстенсивний розвиток обох наукових галузей звичайно знижує рівень взаємозв'язків між ними. 3 іншого боку зростає взаємодія як інженерної механіки, так і автоматизації з іншими (досить різними) галузями знань. Проблема полягає в тім, щоб зберігаючи історичні зв'язки між механікою та автоматизацією, надати новий імпульс їх розвитку. В ОНАХТ це має найти відображення у структурних перетвореннях.

Формулювання цілей дослідження

Мета даного дослідження полягає в тім, щоб проаналізувати теперішній науковий стан механіки та автоматизації в ОНАХТ, його відповідність світовому рівню, а також намітити подальший розвиток цих галузей науки.

Виклад основних результатів та їх обгрунтування

Теорія автоматичного керування (ТАК) вивчає процеси автоматичного або автоматизованого керування об'єктами різноманітної фізичної природи [1]. Основними об'єктами наукового аналізу ТАК є системи автоматичного керування (САК) та автоматизовані система керування (АСК).

Автоматизована система - це сукупність керованого об'єкта та автоматичних керуючих пристроїв, у якій частину функцій керування виконує людина. Автоматизована система являє собою організаційно-технічну систему, що забезпечує вироблення рішень на основі автоматизації інформаційних процесів у різних сферах діяльності (управління, проектування, виробництво тощо) або їх поєднаннях [2].

АСК - це автоматизована система, що грунтується на комплексному використанні технічних, математичних, інформаційних та організаційних засобів для управління складними технічними й економічними об'єктами. АСК є сукупністю керованого об'єкта й автоматичних вимірювальних та керуючих пристроїв, у якій частину функцій виконує людина (ДСТУ 2941-94).

САК - це сукупність керованого об'єкта й автоматичних вимірювальних та керуючих пристроїв. На відміну від автоматизованої системи керування ця система самодіюча і реалізує встановлені функції процеси автоматично, без участі людини (крім етапів пуску та налагодження системи).

В ОНАХТ традиційно науковий інтерес фахівців з автоматизації було сфокусовано на автоматизації технологічних процесів, що знайшло відображення у назві факультету, створеного в 1992 році (факультет АТП). 3 1992-го по 1995ий рік деканом факультету АТП був доцент I.I. Ігнатенко, а з 1995-го по 2002 рік - професор Ю. О. Козак. У цей період факультет інтенсивно готував спеціалістів для автоматизації виробничих процесів у різноманітних галузях, але в першу чергу - для автоматизації технологічних процесів харчових виробництв. 32002 по 2012 р. факультет очолював доцент В.Е. Волков, заступниками декана в цей період працювали доценти Ф.А. Трішин, І.М. Світий, С.О. Воінова.

У 2005 році провідний доцент кафедри АВП В.А. Хобін, розвиваючи теорію керування об'єктами технологічного типу, захистив докторську дисертацію і став професором кафедри. В 2008 році вийшла його монографія «Системи гарантуючого управління технологічними агрегатами: основи теорії, практика застосування».

Світова тенденція зростання рівня зв'язків проблем автоматизації з комп'ютерними науками, бурхливий розвиток комп'ютерно-інтегрованих технологій призвели до того, що у вересні 2006 р. факультет АТП отримав нову назву автоматизації і комп'ютерних систем (АіКС).

ТАК завжди була i $\epsilon$ частиною загальної теорії управління, що вивчає основні принципи $\mathrm{i}$ методи керування різними системами, процесами і об'єктами [3]. Починаючи 3 кінця ХX-го століття в якості 
керованих об'єктів дедалі частіше стали розглядати різноманітні економічні та соціально-економічні системи. У 90-ті роки особливу актуальність набуло вирішення завдань з автоматизації організаційного управління, економічної та бухгалтерської діяльності, інформаційного забезпечення підприємств і закладів, а також розвитку інформаційних технологій. Тому ще у 2004 році, в межах спеціальності «Автоматизоване керування технологічними процесами» було відкрито спеціалізацію «Автоматизоване керування підприємництвом». Перед першим випуском бакалаврів за цією спеціалізацію в березні 2008 року факультет АіКС було перейменовано у факультет автоматизації, комп'ютерних систем і управління підприємництвом (АКСі УП).

32008 року на факультеті АКСі УП за ініціативою завідувача кафедри електротехніки професора П.М. Монтіка було відкрито новий напрям підготовки - «Електромеханіка». Перший набір студентів за цим напрямком було здійснено у 2009 році. Кафедра електромеханіки своїм основним напрямком навчальної та наукової роботи обрала проблеми автоматизованого електроприводу, що є прямим шляхом в робототехніку.

У вересні 2011 р. факультет АКСіУП було перейменовано у факультет автоматизації, електромеханіки, комп'ютерних систем і управління (АЕКСіУ).

Екстенсивний розвиток наукових досліджень з механіки привів до низки перетворень механічного факультету. В вересні 2006 року факультет було перетворено в факультет технологічного обладнання і технічного сервісу (ТОіТС), а в вересні 2011 року вже факультет ТОіТС було реформовано в факультет технологічного обладнання, пакування і технічного дизайну (ТОПіТД).

3 метою підсилення наукових зв'язків між фахівцями 3 інженерної та прикладної механіки 3 одного боку та фахівцями $з$ електромеханіки, автоматизації та комп'ютерно-інтегрованих технологій з іншого боку, 7 вересня 2012 року було створено Навчально-науковий інститут механіки, автоматизації та комп'ютерних систем ім. П.М. Платонова як новий структурний підрозділ академії. Інститут було сформовано на базі кафедр двох факультетів: факультету ТОПіТД та факультету АЕКСіУ. I зовсім невипадково, що інститут носить ім'я Петра Микитовича Платонова, відомого фахівця в галузі механіки та автоматизації. який обіймав посаду ректора академії в $1948-1967$ роки.

3 перших днів його створення інститут очолює Віктор Едуардович Волков, який раніше посідав посаду декана факультету АЕКСіУ. В свою чергу факультет АЕКСіУ очолила к.т.н., доцент О. О. Тітлова.

На час створення інституту до його складу входили наступні кафедри:

- у складі факультету технологічного обладнання, пакування та технічного дизайну: кафедра технологічного обладнання зернових виробництв, кафедра технологічного обладнання харчових виробництв, кафедра теоретичної механіки та машинознавства, кафедра фізики та матеріалознавства, кафедра інженерної графіки та технічного дизайну;

- у складі факультету автоматизації, електромеханіки, комп’ютерних систем та управління: кафедра автоматизації виробничих процесів, кафедра електромеханіки, кафедра процесів, апаратів та енергетичного менеджменту, кафедра вищої математики, кафедра комп'ютерних систем і управління бізнес-процесами.

Основними напрямами науково-дослідної та навчальної роботи в інституті традиційно є інженерна механіка, електромеханіка, автоматизація технологічних процесів і комп'ютерно-інтегровані технології. Крім того, вчені інституту стали більше уваги приділяти найбільш актуальним науковим проблемам.

Під науковим керівництвом професора О.Г. Бурдо, завідувача кафедри процесів, апаратів та енергетичного менеджменту, ведуться масштабні дослідження з двох напрямів - енергетичного менеджменту і нанотехнологій. Ще 3 1997 року функціонує консалтингова лабораторія «ТЕРМА», яка здійснює активну науково-методологічну діяльність в галузі енергоефективності та надає консалтингові послуги з енергетичного менеджменту.

Під керівництвом професора В.Е. Волкова проводяться дослідження в галузі вибухових процесів та вибухобезпеки.

Зусилля науковців відразу кількох кафедр сконцентрувалися в напрямі мехатроніки та робототехніки. На базі кафедри автоматизації виробничих процесів в 2013 році було створено науково-дослідну лабораторію мехатроніки та робототехніки під науковим керівництвом к.т.н., старшого викладача кафедри В.Б. Сгорова.
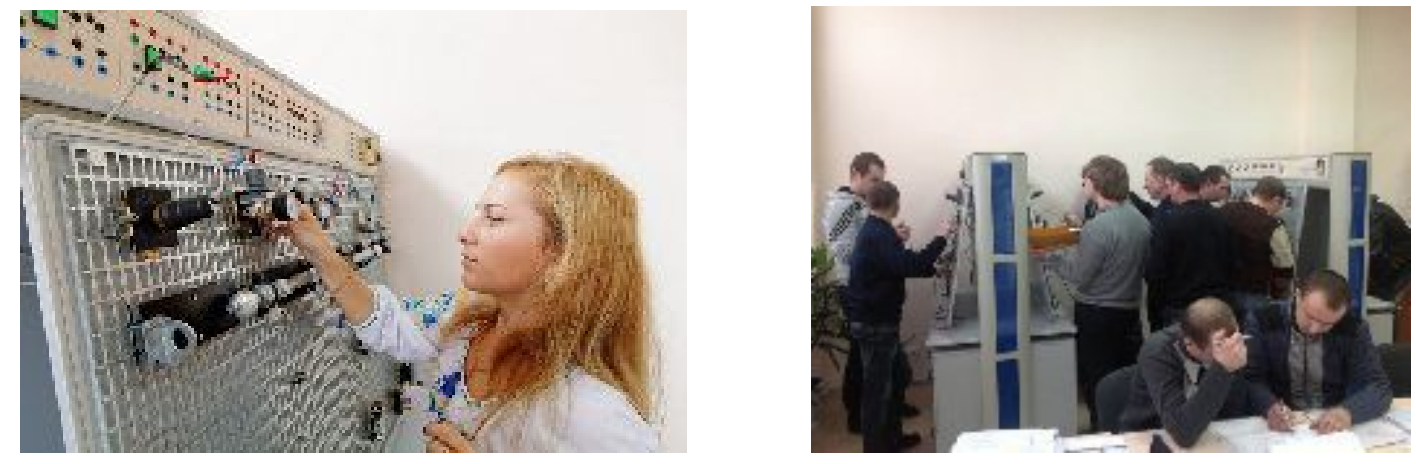

Рис. 2 - В науково-дослідній лабораторії мехатроніки та робототехніки 
Саме розвиток таких напрямів як енергоменеджмент, мехатроніка та робототехніка визначив структурні перетворення в інституті.

37 вересня 2015 р. Навчально-науковий інститут механіки, автоматизації та комп’ютерних систем ім. П.М. Платонова перейменовано в Навчально-науковий інститут механіки, автоматизації та робототехніки ім. П.М. Платонова. Факультет технологічного обладнання, пакування та технічного дизайну перейменовано в факультет енергоменеджменту, технологічного обладнання та технічного дизайну. Факультет автоматизації, електромеханіки, комп'ютерних систем та управління перейменовано в факультет автоматизації, мехатроніки та робототехніки. Кафедру автоматизації виробничих процесів перейменовано в кафедру автоматизації технологічних процесів і робототехнічних систем. На базі кафедри процесів, апаратів та енергетичного менеджменту та кафедри технологічного обладнання харчових виробництв створено кафедру процесів, обладнання та енергетичного менеджменту, яка увійшла до складу факультету енергоменеджменту, технологічного обладнання та технічного дизайну. На базі кафедри електромеханіки та кафедри теоретичної механіки та машинознавства створено кафедру електромеханіки та мехатроніки, яка увійшла до складу факультету автоматизації, мехатроніки та робототехніки.

В теперішній час до складу інституту входять вісім кафедр:

- у складі факультету енергоменеджменту, технологічного обладнання та технічного дизайну: кафедра технологічного обладнання зернових виробництв, кафедра процесів, обладнання та енергетичного менеджменту, кафедра фізики и матеріалознавства, кафедра інженерної графіки та технічного дизайну;

- у складі факультету автоматизації, мехатроніки та робототехніки: кафедра автоматизації технологічних процесів i робототехнічних систем, кафедра електромеханіки та мехатроніки, кафедра вищої математики, кафедра комп'ютерних систем і управління бізнес-процесами.

2015-2017 роки ознаменувався відкриттям і бурхливим розвитком нових спеціалізацій на факультеті автоматизації, мехатроніки та робототехніки - «Автоматизоване управління робототехнічними системами» i «Мехатронні та робототехнічні системи». Ці спеціалізації спрямовані на вивчення, розробку та інтеграцію робототехніки і пристроїв зі штучним інтелектом в усі сфери діяльності людини. В цей період факультет очолював к.т.н. А.Ю. Букарос.

В останні два десятиліття стало очевидним що науковий розвиток автоматизації i, певною мірою, мехатроніки та робототехніки насамперед пов'язаний не стільки з розвитком механіки (теоретичної, прикладної, інженерної), скільки з розвитком комп'ютерної техніки та інформаційних технологій [4]. Цьому є просте пояснення.

Кожна САК містить в собі керуючий пристрій та виконавчі механізми. Керуючий пристрій в сучасній САК - це завжди або комп'ютер, або мікропроцесор. Сучасні фахівці з автоматизації в першу чергу займаються створенням алгоритмів керування та їх реалізацією в керуючому пристрої (тобто в комп’ютері), а це вимагає знання комп’ютерної техніки, інформаційних та комп'ютерно-інтегрованих технологій. Отже науковий розвиток автоматизації неможливий без відповідного розвитку комп’ютерних наук. 3 іншого боку, для розвитку комп’ютерних наук необхідні точки прикладання в інших галузях знань; з цієї точки зору автоматизація, мехатроніка і робототехніки $\epsilon$ такими точками прикладання (найбільш природними та зручними).

Розвиток мехатроніки та робототехніки паралельно стимулює розвиток електромеханіки та механіки. Але розвиток сучасної інженерної механіки має бути екстенсивним, з постійним розширенням галузей ії застосування.

Зважаючи на все вищезазначене, Вчена Рада ОНАХТ 8-го вересня 2017-го року прийняла рішення ліквідувати Навчально-науковий інститут механіки, автоматизації та робототехніки ім. П.М. Платонова та створити Навчальнонауковий інститут комп'ютерних систем і технологій «Індустрія 4.0», присвоївши йому ім'я П.М. Платонова. До нового інституту мають війти не тільки кафедри факультету автоматизації, мехатроніки та робототехніки, що перетворюється в факультет комп'ютерних систем та автоматизації, але й кафедри факультету комп'ютерної інженерії, програмування та кіберзахисту (в який реорганізується факультет інформаційних технологій та кібербезпеки), а саме - кафедри комп'ютерної інженерії та інформаційних технологій та кібербезпеки. Згідно 3 наказом ректора ОНАХТ Б.В. Сгорова від 15.09.2017 рішення Вченої Ради має бути реалізовано 3 1-го лютого 2018 року.

Висновки

Рішення про створення в ОНАХТ нового Навчально-наукового інституту комп'ютерних систем і технологій «Індустрія 4.0» відповідає сучасним світовим тенденціям наукового розвитку механіки, автоматизації та комп’ютерних наук і має стимулювати подальші досягнення науковців в цих галузях знань.

Література

[1] Іванов А.О., Теорія автоматичного керування. / Дніпропетровськ: Національний гірничий університет, 2003.

[2] РД 50-680-88 «Методические указания. Автоматизированные системы. Основные положения».

[3] N. Wiener, Cybernetics: Or Control and Communication in the Animal and the Machine. Paris, (Hermann \& Cie) \& Camb. Mass. / MIT Press, 1948.

[4] Волков В.Э. Информационные технологии: прошлое, настоящее, будущее. / Автоматизация технологических и бизнес-процессов, №20, 2014. - С. 5-15. 


\section{References}

[1] A.O. Ivanov, Teoriya avtomatychnoho keruvannya. Dnipropetrovsk: Natsional'nyy hirnychyy universytet, 2003.

[2] RD 50-680-88 «Metodicheskiye ukazaniya. Avtomatizirovannyye sistemy. Osnovnyye polozheniya».

[3] N. Wiener, Cybernetics: Or Control and Communication in the Animal and the Machine. Paris, (Hermann \& Cie) \& Camb. Mass. (MIT Press), 1948.

[4] V.E. Volkov "Informatsionnyye tekhnologii: proshloye, nastoyashcheye, budushcheye", Automation of technological and business-processes, issue 20, pp. 5-15, 2014.

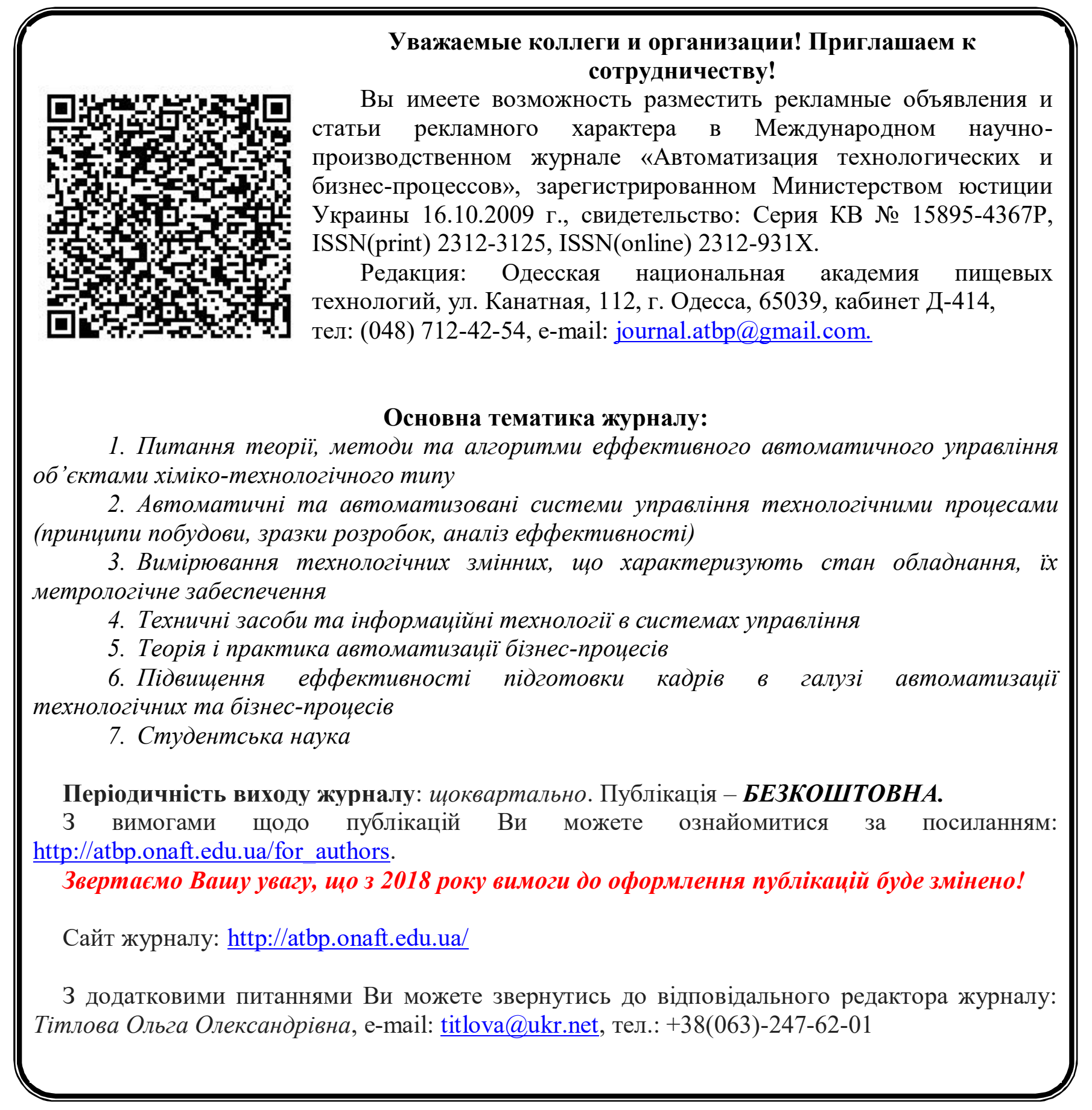

